\title{
Loan and Calque Found in Translation from English to Indonesian
}

\author{
Marlina Adi Fakhrani Batubara \\ A Postgraduate student of Translation Studies in University of Gunadarma, Depok, Indonesia
}

\begin{abstract}
The aim of this article is to find out the cause of using loan and calque found in translation from English to Indonesian, find out which strategy is mostly used in translating some of the words and phrases found in translation from English to Indonesian and what form that is usually use loan and calque in the translation. Data of this article is obtained from the English novel namely Murder in the Orient Express by Agatha Christie and its Indonesian translation. This article concluded that out of 100 data, 57 data uses loan and 47 data uses calque. Moreover, it shows that 70 data are in the form of words that uses loan or calque and 30 data are in the form of phrases that uses loan or calque.
\end{abstract}

Keywords: Translation, Strategy, Loan and Calque.

DOI: $10.7176 /$ JLLL/54-03

Publication date:March $31^{\text {st }} 2019$

\section{INTRODUCTION}

Every country has their own languages in order to express their intentions or to communicate. Language plays a great tool for humans to interact with each other. Goldstein (2008) believed that "We can define language as a system of communication using sounds or symbols that enables us to express our feelings, thoughts, ideas and experiences." (p. 357). Moreover, each country has their own language to communicate, such as Indonesia has Indonesian, China has Chinese, Japan has Japanese as their national language. Language plays a great role in our lives as it is used for us to express our opinion. In our lives, it is used in our daily activities to trade information to others.

As our generation has entered globalization, we are influenced by other culture and language. With this influence, we discover many culture and literary work of other country. One of the most well-known literary works to people is in the form novel. Novel is a book of long narrative in literary prose which tells stories and usually defined as a series of events described in a sequence. In Oxford Dictionary $8^{\text {th }}$ Ed. (2013) "novel is a story long enough to fill a complete book, in which the characters and events are usually imaginary." From the explanation, we can know that novel is a story that has characters and events which usually are fictional in a form of book.

However, despite of the fascination of other country literary work, we tend to not understand the language as it is usually not familiar with us. For instance, even though English is the language of the world, many people in Indonesia still do not know or understand the language. If they do not understand the language, they cannot read the novel. This is why in every country, if they want the novel is understandable to the readers in their country, they have to transfer the language of the novel into the target language. This phenomenon is called translation. Nida and Taber (1974) stated, "Translating consists of reproducing in the receptor language (RL) the closest natural equivalent of the source language (SL) message, first in terms of meaning, and secondly in terms of style" (p.12). They believe that translation is reproduce a text to the target text in the closest equivalent of the source text and sounds natural. In line with Nida and Taber, Newmark (1988) stated, "Translation is rendering the meaning of a text into another language in the way that the author intended the text" (p.5). Catford also (1965) stated, "Translation is an operation performed on languages: a process of substituting a text in one language for a text in another" (p.1). From the explanation from these experts, we can conclude that translation is the process of transferring the meaning of text from one language into another language. The translator is not only translating the meaning from the source text into target text, but also has to sounds natural.

Even though we translate the novel into our language which is to make us understand about the story, we are sometimes borrowing some of the words from other language, especially English words. Weinreich (1968) stated that "Language contact may affect languages in contact through linguistic interferences namely phonemic grammatical and lexical interferences" (p. 62). It means that language can affect of the use of our language in phonemic grammatical and lexical interferences. We are unconsciously borrowed some words from other language and used in our daily live, or in this case in translation. The borrowing of the words is usually undergone semantic changes or borrowing the form of the word without changing anything. This is called loan and calque.

Larson (1998) stated that "A loan word refers to a word which is from another language and is unknown to most of the speakers of the receptor language. Loan words are commonly used for the names of people, places, geographical areas, etc." (p. 186). He believed that loan is when the translator uses the name of people, places or 
geographical areas that is unknown to the target readers. In line with Larson, Cuddon (2013) believed that loan word is "A word imported into a language from another language, or 'borrowed' from it." (p. 407). Newmark also (1988) stated that, "Transference (emprunt, loan word, transcription) is the process of transferring a SL word to a TL text as a translation procedure" (p. 81). From the conclusion above by the experts, loan is a word that is borrowed from one language and retained the lexical unit of the word. Meanwhile, Hatim and Munday (2004) stated that "A calque is a special kind of borrowing whereby a language borrows an expression form of another, but then translates literally each of its elements." (p. 149). In line with Hatim and Munday, Vinay and Darbelnet (1995) "A calque is a special kind of borrowing whereby a language borrows an expression form of another, but then translates literally each of its elements" (p. 32). Molina and Albir (2002) stated that "Calque. A foreign word or phrase translated and incorporated into another language..." (p. 499).

In this research, the researcher wanted to conduct the analysis of loan and calque found in translation from English into Indonesian. The reason of doing this research is because the researcher wanted to find the cause of using loan and calque strategy in translation from English into Indonesian. The researcher will analyze of loan and calque found in translation from English into Indonesian. Loan and calque are usually used in terms of new technical, name of place or unknown concepts. Many translators tend to use these strategies to translate words that they found hard to translate or they cannot find the equivalent translation. In this research, the researcher wishes to explain the effect of using loan and calque strategy in translation from English into Indonesian because using this strategy is common. The researcher has chosen this study namely descriptive translation because the researcher wanted to broaden the researcher's ability and knowledge in analyzing loan and calque found in translation from English into Indonesian.

\section{LITERATURE REVIEW}

In this research, the researcher will present some of the definitions of loan and calque according to other research. Not only calque, but also loan words are discussed as well as their similarities and that many researchers do not explain between the two in their journals. Researchers such as Dorado (2006) and Silva-Corvalán (1994) also explain their definitions of calques and loan. Smead as cited in Dorado (2006) stated that "a calque as a transfer of meaning of the word, not form, while a loan word is transferring the form of the word and its meaning" (p. 5). Same as Smead, Silva-Corvalán (2002) believed that a calque is transferring meaning of the word and adapt it in the lexical item of the target language words. She explains loan words is not only transferring the forms, but also their meanings.

Dorado (2006) argues that "calquing is usually triggered when the speaker does not know a particular word in the target language and therefore will refer to another language to semi-borrow the unknown term. Once this takes place the speaker effects a literal translation into the target language" (p. 1). He believed that calques are semi-borrowed words. In other words, it may be considered as borrowed words because they are borrowing the form of the words from other languages and then adapt them into the target language. For example, the word computer is translated into komputer. The word is semi-borrowed from English word and adapt the form in the target language which is in Indonesian. Moreover, he also believed that loan words are words borrowed from another language. For example, the word internet is still translated into internet. In the translation, the word internet is borrowed and used it in the translation.

However, Nurweni (2013) believed that "Loanwords from one language into another language may undergo some orthographical and semantic changes" (p. 184). Unlike the researchers' statements about loan and calque, Nurweni believed that loanwords may change semantically. He believed that loanwords are not borrowing the words entirely, but there may be a slight change on the target language. Same as Nurweni, Ranty (2011) also believed that "Loanwords are words adopted by the speakers of one language from a different language (the source language). Loanwords refer to the process of the source language into their native language" (p. 2). She also believed that loan words are words that are adopted from one language to another language.

This research does not determine loan words and calque words are the same words because loan and calque are two different strategies. Thus, the focus of this research is which of the strategy is mostly used and what form that is mostly used loan and calque. This research follows Silva-Corvalán's (1995) definition of loan and calque because of its relativity with this research which is a calque is transferring meaning of the word and adapt it in the lexical item of the target language words and loan words are not only transferring the forms, but also their meanings.

\section{METHODOLOGY}

This is qualitative and quantitative research covering the analysis of source text and target text. The analysis of the source text and target text can also be in the form of comparing the source text and the translated text. The source in this research is English and the target text is Indonesian. In comparing the English source text and the Indonesian target text, this research belongs to the descriptive analytical research that will employ the descriptive 
method of exposing the data in line with the topic namely Loan and Calque Found in Translation from English into Indonesian. Based on the topic, the data is the words that is translate using Loan and Calque. Each of the datum will be analysed in accordance what strategy it used. Due to the limited time, the researcher will not be able to handle all of the data, that is why a sample is necessary to be taken. The sample will be randomly taken which means that each datum has an equal opportunity to be chosen. In other words, the method of sampling is called random sampling.

The source of the data of this research is the English version of the Murder on the Orient Express by Agatha Christie and the Indonesian translation with the same title. The novel is chosen as a source of data because the researcher found that the translator used a lot of loans and calques in her translation.

\section{RESULTS}

The results of the research are presented by the chart to show the total data that use of loan and calque found in translation from English to Indonesian. It presents which strategy is mostly used by the translator. In the discussion, the data will be analysed. Figure 1 shows the total of loan and calque found in the translation of the Murder on the Orient Express novel by Agatha Christie. The data that is included obtained from the translation. Figure 1 Total of all loan and calque used in the translation.

Loan and Calque Used in the Translation

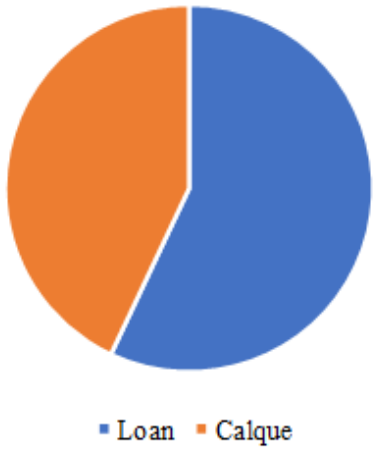

From the chart, it shows that out of 100 data that use both strategies there are 57 data used loan strategy and 43 data used calque strategy. This shows that between two strategies, loan is mostly used by the translator in order to translate some of the words and phrases in the novel.

Figure 2 shows the form of loan and calque found in the translation of the Murder of the Orient Express novel by Agatha Christie. The data that is included obtained from the translation.

Figure 2 Form of loan and calque in the translation.



This chart shows that out of 100 data that use both strategies are 70 data are in the form of words and 30 data are in the form of phrases. This shows that the forms that are mostly used loan or calque in the translation is in the form of words.

\section{ANALYSIS}

A total of 100 data are identified in the target text which is in Indonesian. Out of the 100 data that is identified, there are 57 data that use loan strategy and 43 data that use calque strategy. Most of the forms that use loan or 
calque are words. There are 70 data that is in the form of words and 30 data are in the form of phrases. The collected data in the target language of the novel shows the kind of the strategy that is used on the datum. In this analysis, a word that is translated into Indonesian does not always use loan or calque only. Therefore, each datum uses different strategy, whether it uses loan or calque strategy in order to translate it. In this section, each data will be discussed based on what strategy it uses.

\section{a. Translation Uses Loan Strategy}

The analysis reveals that 57 data that is translated using loan as the strategy. The words are retained from the source text and put in the target text. In this section, the researches will use 5 data that uses loan to be analyzed.

Data 1

\begin{tabular}{|l|l|}
\hline Source Language Text & Target Language Text \\
\hline $\begin{array}{l}\text { When Poirot rejoined his friend in the } \\
\text { lounge, the other two men were just leaving } \\
\text { the hotel. }\end{array}$ & $\begin{array}{l}\text { Sewaktu Poirot menemui teman lamanya kembali di } \\
\text { ruang duduk, kedua laki-laki itu tampak sedang bersiap- } \\
\text { siap untuk meninggalkan hotel. }\end{array}$ \\
$\begin{array}{l}\text { Christie (2017). Murder on the Orient } \\
\text { Express. Great Britain: Collins, p. } 6\end{array}$ \\
$\begin{array}{l}\text { Orient Express. (Buditbatjahja, 2018). Gramedia Pustaka } \\
\text { Utama, p. } 17\end{array}$
\end{tabular}

It can be seen on Data 1 that the word ...hotel... in the source text is translated into ...hotel... in the target text. In bilingual dictionary, ...hotel... in English is translated into ...hotel... with the same spelling. The meaning of word ...hotel... is not given in the translation for the target text's readers. Even though there is no explanation of the word in the translation, the target text's readers may be aware of what hotel is. This kind of strategy is called as loan.

Data 2

\begin{tabular}{|l|l|}
\hline Source Language Text & Target Language Text \\
\hline $\begin{array}{l}\text { There were three waiting for him and a } \\
\text { telegram. His eyebrows rose a little at the } \\
\text { sight of the telegram. It was unexpected. }\end{array}$ & $\begin{array}{l}\text { Ada tiga buah surat dan satu telegram. Nampak ia } \\
\text { mengerutkan kening sebentar sewaktu melihat telegram } \\
\text { itual itu sungguh di luar dugaannya, }\end{array}$ \\
\hline Christie (2017). Murder on the Orient & $\begin{array}{l}\text { Pembunuhan di Orient Express (trans). Murder on the } \\
\text { Express. Great Britain: Collins, p. } 14\end{array}$ \\
$\begin{array}{l}\text { Orient Express. (Buditbatjahja, 2018). Gramedia Pustaka } \\
\text { Utama, p. } 27\end{array}$
\end{tabular}

From Data 2, we can see that the word ...telegram... in the source text is translated into ...telegram... in the target text. In bilingual dictionary, ...telegram... in English is translated into ...telegram... with the same spelling. The meaning of the word ...telegram... is not given in the translation for the target text's readers. The target text's readers may have understood what telegram is without any explanation of the word in Indonesian. This kind of strategy is called loan.

\section{Data 3}

\begin{tabular}{|l|l|}
\hline Source Language Text & Target Language Text \\
\hline $\begin{array}{l}\text { Neither in the train to Kirkuk, nor in the Rest } \\
\text { House at Mosul, nor last night on the train had she } \\
\text { slept properly }\end{array}$ & $\begin{array}{l}\text { Ada tiga buah surat dan satu telegram. Nampak ia } \\
\text { mengerutkan kening sebentar sewaktu melihat } \\
\text { telegram itu. Hal itu sungguh di luar dugaannya, }\end{array}$ \\
\hline $\begin{array}{l}\text { Christie (2017). Murder on the Orient Express. } \\
\text { Great Britain: Collins, p. } 6\end{array}$ & $\begin{array}{l}\text { Pembunuan di Orient Express (trans). Murder } \\
\text { on the Orient Express. (Buditbatjahja, 2018). }\end{array}$ \\
\hline
\end{tabular}

It can be seen in Data 3 that the phrase ...Rest House... is translated into ...Rest House... in the target text. The phrase ... Rest House... is retained from the source text into the target text. It is also shown that the translator does not give any explanation about the phrase as the readers of the target text may be aware that the phrase ...Rest House... is a name of a place which does not need any explanation of what the phrase is. This kind of strategy is called loan.

Data 4

\begin{tabular}{|c|c|}
\hline Source Language Text & Target Language Text \\
\hline $\begin{array}{l}\text { On arrival at the Galata Bridge he drove } \\
\text { straight to the Tokatlian Hotel. }\end{array}$ & $\begin{array}{l}\text { Begitu sampai di Galata Bridge detektif Belgia } \\
\text { itu langsung menuju Hotel Tokatlian. }\end{array}$ \\
\hline $\begin{array}{l}\text { Christie (2017). Murder on the Orient } \\
\text { Express. Great Britain: Collins, p. } 13\end{array}$ & $\begin{array}{l}\text { Pembunuhan di Orient Express (trans). Murder } \\
\text { on the Orient Express. (Buditbatjahja, 2018). } \\
\text { Gramedia Pustaka Utama, p. } 26\end{array}$ \\
\hline
\end{tabular}

From Data 4, we can see that the phrase ...Galata Bridge... is translated into ...Galata Bridge... in the target text. The phrase ...Galata Bridge... is retained from the source text into target text. From the data, we can see that the translator also does not translate the phrase literally in Indonesian and does not 
give any explanation about the phrase. The readers of the target text may not need any explanation about the phrase as it is a name of a place, so it is not necessary to give further explanation or translate it literally. This strategy is called loan.

\section{Data 5}

\begin{tabular}{|l|}
\hline Source Language Text \\
\hline M. Bouc was a Belgian, a director of the \\
Compagnie Internationale des Wagons Lits, \\
and his acquaintance with the former star of the \\
Belgian police force dated back many years.
\end{tabular}

Christie (2017). Murder on the Orient Express.

Great Britain: Collins, p. 48

Target Language Text

Buoc juga seorang BeIgia, seperti Poirot, jabatannya direktur Compagnie Internationale des Wagons Lits dan persahabatannya dengan detektif BeIgia yang cemerlang itu sudah berjalan bertahun- tahun lamanya.

Pembunuhan di Orient Express (trans). Murder on the Orient Express. (Buditbatjahja, 2018).

Gramedia Pustaka Utama, p. 71

It can be seen in Data 5 that the phrase ...Compagnie Internationale des Wagons Lits... is translated into ...Compagnie Internationale des Wagons Lits... in the target text. The phrase from the source text is retained the target text. In other words, the translator uses the phrase from the source text without translating it literally. As we can see, in the target text, the translator does not give any explanation about the phrase. This happens because the phrase is the name of a company and it does not require any explanation. This strategy is called loan.

\section{b. Translation Uses Calque Strategy}

The analysis reveals that 43 data that is translated using calque as the strategy. The words are borrowed from the source text and adapted the words in the target text. In this section, the researches will use 5 data that uses calque to be analyzed.

Data 1

\begin{tabular}{|l|l|}
\hline Source Language Text & Target Language Text \\
\hline $\begin{array}{l}\text { 'I have the tickets of Monsieur. I will also take } \\
\text { the passport, please. Monsieur breaks his } \\
\text { journey in Stamboul, I understand? }\end{array}$ & $\begin{array}{l}\text { "Saya punya karcis Anda, dan kalau boleh saya } \\
\text { juga ingin lihat paspor Anda. Anda turun di } \\
\text { Istanbul, bukan? }\end{array}$ \\
$\begin{array}{ll}\text { Christie (2017). Murder on the Orient Express. } & \begin{array}{l}\text { Pembunuhan di Orient Express (trans). Murder } \\
\text { on the Orient Express. (Buditbatjahja, 2018). }\end{array} \\
\text { Great Britain: Collins, p. } 7 & \text { Gramedia Pustaka Utama, p. 18-19 }\end{array}$
\end{tabular}

From Data 1, we can see that the word ...passport... in the English source text is adopted into ... paspor ... in the Indonesian language. There is an omission of the letters $\mathbf{s}$ and $\mathbf{t}$ in the word passport which becomes paspor. The word is borrowed from English word and the lexical unit is adapted in the target language which is into Indonesian. In other words, the word has the equivalent translation which is adapting the word into Indonesian. This strategy is called calque.

Data 2

\begin{tabular}{|l|l|}
\hline Source Language Text & Target Language Text \\
\hline $\begin{array}{l}\text { When he awoke it was half-past nine, and he } \\
\text { sallied forth to the restaurant-car in search of } \\
\text { hot coffee. }\end{array}$ & $\begin{array}{l}\text { Sewaktu terbangun, sudah pukul Sembilan tiga } \\
\text { puluh. Bergegas-gegas ia pergi ke ruang restorasi } \\
\text { dan langsung memesan secangkir kopi panas. }\end{array}$ \\
\hline $\begin{array}{l}\text { Christie (2017). Murder on the Orient } \\
\text { Express. Great Britain: Collins, p. } 8\end{array}$ & $\begin{array}{l}\text { on the Orient Express. (Buditbatjahja, 2018). } \\
\text { Gramedia Pustaka Utama, p. 19 }\end{array}$
\end{tabular}

From Data 2, we can see that the word ...coffee... in the English source text is adopted into ... kopi ... in the Indonesian language. There is a change on the letter $\mathbf{c}$ into $\mathbf{k}$, double $\mathbf{f}$ and $\mathbf{e}$ into $\mathbf{p}$ and $\mathbf{i}$ in the word coffee which becomes kopi. The word is borrowed from English word and the lexical unit is adapted in the target language which is into Indonesian. In other words, the word has the equivalent translation which is adapting the word into Indonesian. This strategy is called calque.

Data 3

\begin{tabular}{|l|l|}
\hline Source Language Text & Target Language Text \\
\hline $\begin{array}{l}\text { Colonel Arbuthnot talked of the Punjab, and } \\
\text { occasionally asked the girl a few questions } \\
\text { about Baghdad where is became clear that she } \\
\text { had been in a post as governess. }\end{array}$ & $\begin{array}{l}\text { Kolonel Arbuthnot bercerita tentang Punjab, } \\
\text { dan ia sesekali bertanya mengenai Bagdad } \\
\text { kepada wanita muda itu, yang ternyata bekerja } \\
\text { di Bagdad sebagai guru privat. }\end{array}$ \\
$\begin{array}{l}\text { Christie (2017). Murder on the Orient Express. } \\
\text { Great Britain: Collins, p. } 9\end{array}$ & $\begin{array}{l}\text { Pembunuhan di Orient Express (trans). Murder } \\
\text { on the Orient Express. (Buditbatjahja, 2018). } \\
\text { Gramedia Pustaka Utama, p. } 21\end{array}$
\end{tabular}


From Data 3, we can see that the word ...Baghdad... in the English source text is adopted into ... Bagdad ... in the Indonesian language. There is an omission on the letters $\mathbf{h}$ in the word Baghdad which becomes Bagdad. The word is borrowed from English word and the lexical unit is adapted in the target language which is into Indonesian. In other words, the word has the equivalent translation which is adapting the word into Indonesian. This strategy is called calque.

Data 4

\begin{tabular}{|l|l|}
\hline Source Language Text & Target Language Text \\
\hline $\begin{array}{l}\text { 'Rather an odd little comedy that I watch here,' } \\
\text { said Poirot to himself thoughtfully. }\end{array}$ & $\begin{array}{l}\text { "Persis seperti komedi kecil yang ganjil, yang } \\
\text { sedang kulihat ini," ujar Poirot dalam hati. }\end{array}$ \\
\hline $\begin{array}{l}\text { Christie (2017). Murder on the Orient Express. } \\
\text { Great Britain: Collins, p. } 11\end{array}$ & $\begin{array}{l}\text { Pembunuhan di Orient Express (trans). Murder } \\
\text { on } \text { the Orient Express. (Buditbatjahja, 2018). }\end{array}$ \\
\hline
\end{tabular}

From Data 4, we can see that the word ...comedy... in the English source text is adopted into ... komedi... in the Indonesian language. There is a change of the letter $\mathbf{c}$ into $\mathbf{k}$ and $\mathbf{y}$ into $\mathbf{i}$ in the word comedy which becomes komedi. The word is borrowed from English word and the lexical unit is adapted in the target language which is into Indonesian. In other words, the word has the equivalent translation which is adapting the word into Indonesian. This strategy is called calque.

Data 5

\begin{tabular}{|l|l|}
\hline Source Language Text & Target Language Text \\
\hline $\begin{array}{l}\text { M. Bouc was a Belgian, a director of the } \\
\text { Compagnie Internationale des Wagons Lits, } \\
\text { and his acquaintance with the former star of the } \\
\text { Belgian police force dated back many years. }\end{array}$ & $\begin{array}{l}\text { Buoc juga seorang BeIgia, seperti Poirot, } \\
\text { jabatannya direktur Compagnie Internationale } \\
\text { des Wagons Lits dan persahabatannya dengan } \\
\text { detektif BeIgia yang cemerlang itu sudah } \\
\text { berjalan bertahun- tahun lamanya. }\end{array}$ \\
\hline $\begin{array}{l}\text { Christie (2017). Murder on the Orient Express. } \\
\text { Great Britain: Collins, p. 11 }\end{array}$ & $\begin{array}{l}\text { Pembunhan di Orient Express (trans). Murder } \\
\text { Gramedia Pustaka Utama, p. } 23\end{array}$
\end{tabular}

From Data 5, we can see that the word ...director... in the English source text is adopted into ... direktur ... in the Indonesian language. There is a change on the letters $\mathbf{c}$ and $\mathbf{k}$ and $\mathbf{o}$ into $\mathbf{u}$ in the word director which becomes direktur. The word is borrowed from English word and the lexical unit is adapted in the target language which is into Indonesian. In other words, the word has the equivalent translation which is adapting the word into Indonesian. This strategy is called calque.

\section{RESULTS}

The aim of this research is to find out which strategy that is mostly used in the translation, whether it is loan or calque. The research is focusing on the novel Murder on the Orient Express and tries to identify the data that use loan or calque strategy. The strategy is used to show what strategy that is used in the target text. Based on the analysis of the collected data, the use of two translation strategy are explained. The strategy that is mostly used in translating the data in the novel Murder on the Orient Express is loan. This shows that the translator is mostly borrowed the words or phrases and retained the lexical item in the target text. Moreover, the data that is used calque are also many. This shows that even though the translator is mostly using loan, the translator is also used calque because some of the translation of the words or phrases have the Indonesian translation, even though it is borrowing the English words and has a slight change on the lexical item of the target text.

The translation shows that many of the English words or phrases are mostly borrowed and retained in the target text. This shows that most of the words are taken from English words and kept it as it is without changing or omitting any lexical unit on the words or phrases. As we are influenced by other language, especially English, we are unconsciously borrowed the words and uses it the way the origin of the word's lexical unit. Borrowing the words from the original language are mostly retained, but sometimes it is borrowed and has undergone sematic changes in the target language. The researcher finds that the translator mostly used loan to translate the data. This research is not only to distinguish loan and calque, but also the criteria of the use of loan and calque on the words and phrases. This research also shows what strategy that translator uses in her translation and gives the possible reasons of why the translator uses the strategy.

\section{CONCLUSIONS}

The research finds that the translator uses loan and calque strategy in order to translate some of the words or phrases from the source text into the target text. Most of the words are usually does not have the translation in which in Indonesian lexical unit and the translator has to use the original word from the source text in the target text. However, the translator does not need to give the explanation of the words or phrases. The words or phrase are mostly familiar and also written in the same form of the English words in Indonesian or it is the name of a 
place which does not need further explanation.

This research also shows that the most dominant form that uses loan or calque is words. The translator is mostly borrowing the words from the source text which is English and put it in the target text which Indonesian and keep the lexical unit from the target text, or in other words uses loan. Not only loan, but the words also uses calque as the strategy to translate them. The translator adapts the words from the source text and slightly change the lexical unit on the target text.

\section{ACKNOWLEDGEMENTS}

I would like to express my deepest gratitude for the Master Program of Translation Studies in University of Gunadarma. The place where I have learned and given knowledge of translation studies which I am grateful to be able to learn it. Thank you to Prof. Dr. Ratna Sayekti who teaches us about translation, from the theories, principles and strategies used in order to translate a text. Lastly, I would like to thank Dr. Ichwan Suyudi M, M. who gives me advice and ideas, so that I can construct this research.

\section{REFERENCES}

Books

Catford, J. C. (1965). A Linguistic Theory of Translation: An Essay in Applied Linguistics. UK: Oxford University Press.

Christie, Agatha. (2017). Murder in the Orient Express. Great Britain: Collins

Cuddon, J. A. (2013) A Dictionary of Literary Terms and Literary Theory. USA: Blackwell Publishers.

Goldstein, E. Bruce. (2008). Cognitive Psychology: Connecting Mind, Research and Everyday Experience, $2^{\text {nd }}$ Ed. USA: Wadsworth.

Hatim, Basil \& Munday, Jeremy. (2004). Translation: An advanced resource book. USA: Routledge.

Hornby, Turnbull, J., Lea, D., Parkinson, D., Phillips, P., Francis, B., ... Ashby, Michael. (2010). Oxford Advanced Learner's Dictionary, 8th Edition International Student's Edition. OUP Oxford.

Larson, Mildred. L. (1998). Meaning-Based Translation: A Guide to Cross-Language Equivalence. UK: British Library Cataloging.

Newmark, Peter. (1988). A Textbook of Translation. Great Britain: Wheaton \& Co. Ltd, Kxeter.

Nida, Eugene A., \& Taber, Charles R. (1974). The Theory and Practice of Translation.

Vinay, J. P \& Darbelnet, J. (1995). Comparative Stylistics of French and English. Amsterdam: John Benjamins

Weinreich, Uriel. (1968). Languages in Contact: Findings and Problems. Den Haag. The Hague.

\section{Journals}

Dorado, Dorian. (2006). Spanish-English Bilinguals in Gainesville, Florida: A Crossgenerational Study of the Use of Calques. USA: University of Florida.

Molina, Lucía \& Albir, Amparo Hurtado. (2002). Translation Techniques Revisited: A Dynamic and Functionalist Approach. Spain: Universitat Autònoma de Barcelona.

Nurweni, Ari. (2013). Meanings of English Loanwords in Indonesian Articles of Sport. Media Neliti.

Ranty, Festy. (2011). The Meaning Analysis of English Loanwords in Indonesian (Case Study: Kompas Newspaper). Indonesia: University of Gunadarma.

Silva-Corvalán, C. (1994). Language contact and change: Spanish in Los Angeles. New York: Clarendon Press. 